\title{
Hemşirelik Öğrencilerinin Sağlıklı Yaşam Biçimi Davranışları İle Yaşam Kaliteleri Arasındaki İlişkinin Belirlenmesi
}

\author{
Kübra Güneş ${ }^{1}$, Gizem Şahin ${ }^{2}$ \\ ${ }^{1}$ Uludağ Üniversitesi Sağlık Uygulama ve Araştırma Merkezi Hastanesi Kalp Damar Cerrahisi Anabilim Dalı \\ Yoğun Bakım Ünitesi Bursa, Türkiye \\ ${ }^{2}$ Cerrahpaşa Florence Nightingale Hemşirelik Fakültesi Ruh Sağlığı ve Psikiyatri Hemşireliği Anabilim Dalı \\ İstanbul, Türkiye
}

email: kubragunes213@gmail.com, agizemsahin@gmail.com

Orcid: 0000-0003-4350-5343

Orcid: 0000-0002-2251-2125

*Sorumlu Yazar / Corresponding Author: Sorumlu Yazar: Gizem Şahin

Gönderim Tarihi / Received: 11.02.2019

Kabul Tarihi / Accepted: 08.08.2019

DOI: $10.34087 /$ cbusbed.525733

\begin{abstract}
Amaç:Bu araştırma, hemşirelik öğrencilerinin sağlıklı yaşam biçimi davranışları ile yaşam kaliteleri arasındaki ilişkinin belirlenmesi amacıyla planland.

Gereç ve Yöntem:Kesitsel tipte yapılan bu araştırmanın evrenini, bir vakıf üniversitesinde eğitim alan 255 öğrenci, örneklemi ise araştırmaya katılmayı kabul eden 181 öğrenci oluşturdu. Araştırma verileri etik kurul ve kurum izni tamamlandıktan sonra; 31 Ocak - 10 Şubat 2017 tarihleri arasında Kişisel Bilgi Formu, Sağlıklı Yaşam Biçimi Davranışları-II ve SF-36 Formu ile toplandı. Çalışmanın amacı katılımcılara açıklandı ve yazılı onamları alındı.

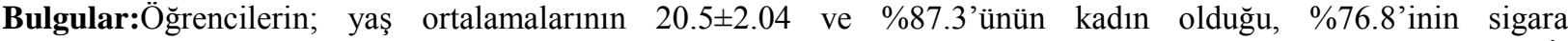
kullanmadığı, \%79'unun alkol kullanmadığ1, \%93.9'unun kronik hastalığının olmadığı ve beden kitle indeksi (BKI) değerlerinin ortalamasının $22.1 \pm 3.17$ olduğu belirlendi. Öğrencilerin SYBDÖ-II ölçek toplam puan ortalamas1 $132.52 \pm 20.05$, SF-36 ölçeği alt boyutları puan ortalamaları ise; fiziksel fonksiyon için $90.71 \pm 11.28$, fiziksel rol kısıtlaması için 86.04 \pm 28.05 , emosyonel rol kısıtlaması için 64.64 \pm 38.51 , vitalite için 57.34 \pm 16.10 , sosyal fonksiyon için $71.75 \pm 20.0$, ağrı için $74.65 \pm 19.05$, mental sağlık için $65.87 \pm 14.96$ ve genel sağlık algisı için $65.24 \pm 14.26$ olarak bulundu. SYBDÖ-II toplam puanı ile KF-36 ölçeğinin fiziksel fonksiyon (r=0.157) ve emosyonel rol kısıtlaması ( $\mathrm{r}=0.149)$ alt boyutları ile çok düşük, vitalite $(\mathrm{r}=0.367)$, mental sağlık $(\mathrm{r}=0.323)$, sosyal fonksiyon ( $\mathrm{r}=0.242)$ ve genel sağlık algısı $(\mathrm{r}=0.261)$ ile düşük düzeyde pozitif yönde anlamlı ilişki belirlendi.

Sonuç:Araştırmanın sonucunda; hemşirelik öğrencilerinin, sağlıklı yaşam biçimi davranışları ile yaşam kaliteleri arasında anlamlı ilişkinin olduğu belirlendi.
\end{abstract}

Anahtar Kelimeler: Hemşirelik Öğrencileri, Sağlıklı Yaşam Tarzı, Davranış, Yaşam Kalitesi.

Abstract
Objective :This research was conducted to determine the relationship between healthy lifestyle behaviors and
quality of life of nursing students.
Methods: This study consisted of a cross sectional type, the universe consisting of 255 students receiving nursing
education at a foundation university and the sample consisting of 181 nursing students who agreed to participate in
the research. Research data was collected with The Personal Data Form, The Healthy Life Style Behavior Scale-II
(HPLP-II) and Short Form - 36 (SF-36) between January 31 and February 10,2017 . Ethics committee approval,
institutional work permit and informed consent of the cases were taken in order to conduct the research.
Results:Student's mean age was $20.5 \pm 2.04$ and $87.3 \%$ of students were female, $76.8 \%$ of them didn't smoke, $79 \%$
of them didn't use alcohol, $93.9 \%$ of them didn't have chronic disease, and BMI was $22.1 \pm 3.17$. The mean score of
HLSBS-II scale was $132.52 \pm 20.05$. The mean scores of SF-36 subscales were $90.71 \pm 11.28$ for physical function,
$86.04 \pm 28.05$ for emotional role restriction, $57.34 \pm 16.10$ for vitality, $71.75 \pm 20.0$ for social function, $74.65 \pm 19.05$ for
pain, $65.87 \pm 14.96$ for mental health and $65.24 \pm 14.26$ for general health perception. A significant positive
correlation was found between physical function $(\mathrm{r}=0.157)$, emotional role restriction $(\mathbf{r}=\mathbf{0 . 1 4 9})$, vitality $(\mathbf{r}=\mathbf{0 . 3 6 7})$,


mental health $(r=0.323)$, social function $(r=0.242)$ and general health perception $(r=0.261)$ components of the $S F-36$ form with the HLSBS-II total score of the students.

Conclusion:As a result of the research; it was determined that there was a positive correlation between healthy lifestyle behaviors and quality of life of nursing students.

Keywords: Nursing Students, Healthy Lifestyle, Behavior, Quality Of Life.

\section{Giriş}

İyilik hali ya da sağlık algısı; daha bütüncül bir yaklaşımla, bireyin ve toplumun istekleri doğrultusunda gereksinimlerini karşıladığı, sağlığı koruyan ve sürdüren bir olgu olarak öngörülmektedir. Bu olgu; bireyin kendi sağlığı ile ilgili etkin kararlar alarak kendi kendine gerçekleştirebileceği davranışları ve içinde yaşadığ çevrenin değişimini içeren kaliteli bir yaşam üzerine dayandırılmıştır $[1,2]$. Bireylerin yaşam biçimleri yaşam kalitesini ve süresini etkilemektedir.

Sağlıklı yaşam biçimi davranışları, bireyin sağlıklı yaşamak ve hastalıklardan korunarak kaliteli bir yaşam sürmek için inandığ 1 ve uyguladığ şeklinde tanımlanmaktadır [1]. Sağlığa duyarlılığın artması ile bireyin yaşam kalitesi artar, hastalıklara yol açan yaşam biçimleri değişir ve sağlıklı yaşam biçimi davranışı kazanır. Bu davranışların alışkanlık haline gelmesi ve sağlık algısını geliştirmek için bireye yeterli bilgi, beceri ve olumlu davranışların kazandırılması gerekir. $\mathrm{Bu}$ da doğru sağlık davranışlarının yaşamın erken dönemlerinden itibaren kazandırılması ile sağlanabilmektedir [3]. Hemşirelik öğrencilerinin sağlık durumunu olumlu olarak algılamaları, sağlıklı yaşam biçimi davranışlarını sürdürmeyi olumlu yönde etkiler ve yaşam kalitelerini yükseltir [4]. Hemşirelik öğrencilerinin akademik eğitimlerinden itibaren sağlıklarını korumanın ve geliştirmenin önemini kavramaları ve sağlıklı yaşam biçimi davranışlarını kullanmaları beklenmektedir [5]. Yapılan çalışmalarda; gerek hemşirelik öğrencilerinin gerekse sağlık programlarındaki diğer öğrencilerin sağlıklı yaşam biçimi davranışlarını tam kazanamadıkları saptanmıştır [6-9]. Bu bağlamda; bu araştırma, hemşirelik öğrencilerinin sağlıklı yaşam biçimi davranışları ile yaşam kaliteleri arasındaki ilişkinin belirlenmesi amaciyla planlandi.

\section{Gereç ve Yöntem}

\subsection{Araştırmanın Tipi, Evren ve Örneklemi}

Kesitsel tipte planlanan araştırmanın evrenini, bir vakıf üniversitesinin Hemşirelik Bölümü'nde 2016 - 2017 akademik yarıyılında öğrenim gören 255 hemşirelik öğrencisi oluşturdu. Tam sayım yöntemi kullanılan bu araştırmada, katılmak istemeyen öğrencilerin olması nedeniyle 181 hemşirelik öğrencisi ile araştırma yürütüldü. Araştırmanın katılım oranı \% 70.9'dur.

\subsection{Veri Toplama Araçları}

Kişisel Bilgi Formu: Hemşirelik öğrencilerinin, yaş, cinsiyet, sınıf, aile yapısı, yaşadığı yer, sigara kullanım durumu, alkol kullanım durumu, kronik hastalığa sahip olma durumu ve beden kitle indeksine (BKI) ait dokuz sorunun yer aldığ 1 form, ilgili literatür taranarak araştırmacılar tarafindan oluşturuldu $[1,5,10]$.
Sağlıklı Yaşam Biçimi Davranışları Ölçeği-II (SYBDÖII): Ölçek ilk olarak 1987 yılında Pender ve arkadaşları tarafından geliştirilmiştir. Daha sonra Walker ve arkadaşları (1996) bu ölçeği güncelleyerek Sağlıklı Yaşam Biçimi Davranışları-II olarak adlandırmışlardır. SYBDÖ-II ölçeğinin Türkçe geçerlik - güvenirlik çalışması ise Bahar ve arkadaşları (2008) tarafindan yapılmıştır. SYBDÖ-II ölçeği 52 maddeden oluşan 4'lü likert tipinde bir ölçektir. Ölçeğin maddeleri Hiçbir Zaman (1), Bazen (2), Sık Sık (3) ve Düzenli Olarak (4) şeklinde puanlanmaktadır. Ölçek; "sağlık sorumluluğu", "fiziksel aktivite", "beslenme", "manevi gelişim", "kişilerarası ilişkiler" ve "stres yönetimi" olmak üzere toplam altı alt boyuttan oluşmaktadır. Ölçekten alınabilecek toplam puan aralığ $52-208$ 'dir. Toplam puanın artması, kişinin daha fazla sağlıklı yaşam biçimi davranışına sahip olduğunu gösterir. Ölçeğin cronbach's alpha iç tutarlılık katsayısı 0.92'dir [11]. Kısa Form 36 (KF - 36): Ölçek 1987 yılında Ware tarafından geliştirilmiştir. Ölçeğin Türkçe geçerlik - güvenirlik çalışması Koçyiğit ve arkadaşları tarafından (1999) yapılmıştır. Bu ölçekte sağlık; "fiziksel fonksiyon", "fiziksel rol kisitlaması", "emosyonel rol kisitlaması", "sosyal fonksiyon", "mental sağlık", "vitalite”, “ağrı" ve "genel sağlık algısı" olmak üzere sekiz alt boyutta ele alınmaktadır. SF-36 ölçeğinde 100 puan üzerinden puanlama yapılmaktadır ve alınan puanlar her boyut için 0-100 puan arasındadır. Ölçeğin toplam puanı bulunmamaktadır. Bu ölçekte 100 puan iyi bir sağlık durumunu gösterirken, 0 puan kötü sağlık durumunu göstermektedir. Ölçeğin geçerlik - güvenirlik çalışmasında her bir alt boyut için cronbach's alpha iç tutarlılık katsayıları 0.73 ile 0.76 arasında değişmektedir [12].

\subsection{Veri Toplama}

Araştırmanın verileri; İstanbul ilinde yer alan bir vakıf üniversitesinde, 31 Ocak 2017 - 10 Şubat 2017 tarihleri arasında araştırmaya katılmayı kabul eden öğrenciler ile yüz yüze görüşme yöntemi ile topland1. Görüşme yaklaşık 15 dakika sürdü.

\subsection{Araştırmanın Etik Yönü}

Araştırmanın etik kurul izni 22.12.2016 tarihinde ATADEK-2016/20 karar numarası ile alındı. Araştırmanın yapılabilmesi için kurum çalışma izni alındı. Araştırmaya katılmayı kabul eden öğrenciler bilgilendirildi ve öğrencilerden yazılı onam alındı.

\subsection{Verilerin Değerlendirilmesi}

Araştırmanın verileri SPSS 21.0 istatistik paket programı ile değerlendirildi. Verilerin analizinde frekans, yüzde, ortalama, standart sapma ve pearson korelasyon analizi kullanıldı. İki bağımsız grubun istatistiksel analizinde parametrik test varsayımları sağlanmadığından Mann-Whitney U testi, ikiden fazla bağımsız grubun istatiksel analizinde parametrik test 
varsayımları sağlanmadığından Kruskal-Wallis $H$ testi kullanıldı. Sonuçlar \%95'lik güven aralığında, $\mathrm{p}<0.05$ anlamlılık düzeyinde değerlendirildi.

\section{Bulgular}

Tablo 1'e bakıldığında öğrencilerin; yaş ortalamalarının $20.5 \pm 2.04$ ve beden kitle indeksi (BKİ) değerleri ortalamasının $22.1 \pm 3.17$ olduğu; \%87.3'ünün kadın; \%24.3'ünün birinci, \%30.4'ünün ikinci, \%19.9'unun üçüncü ve \%25.4'ünün dördüncü sınıf öğrencisi olduğu, \%90.6'sının çekirdek aile yapısına sahip olduğu ve \%66.9'unun evde ebeveynleri ile yaşadığı saptandı. Öğrencilerin \%76.8'inin sigara tüketmediği, \%79'unun alkol kullanmadığı ve \%93.9'unun kronik hastalığının olmadığ1 belirlendi. Öğrencilerin SYBDÖ-II puan ortalamalarına bakıldığında; ölçek toplam puan ortalamasının 132.52 \pm 20.05 , sağlık sorumluluğu alt boyutu puan ortalamasının $21.97 \pm 4.38$, fiziksel aktivite alt boyutu puan ortalamasinın $17.89 \pm 5.21$, manevi gelişim alt boyutu puan ortalamasının 26.46 \pm 4.72 , kişilerarası ilişki alt boyutu puan ortalamasının $26.11 \pm 4.52$, stres yönetimi alt boyutu puan ortalamasının $19.51 \pm 3.89$ ve beslenme alt boyutu puan ortalamasının $20.5 \pm 4.00$ olduğu görüldü (Tablo 2 ).

Öğrencilerin KF-36 alt boyutlarının puan ortalamaları ise; fiziksel fonksiyon için $90.71 \pm 11.28$, fiziksel rol kısıtlaması için $86.04 \pm 28.05$, emosyonel rol kısıtlaması için $64.64 \pm 38.51$, vitalite için $57.34 \pm 16.10$, sosyal fonksiyon için $71.75 \pm 20.0$, ağrı için $74.65 \pm 19.05$, mental sağlık için $65.87 \pm 14.96$ ve genel sağlık algısı için 65.24 \pm 14.26 'dır (Tablo 2).

Öğrencilerin yaș ve BKİ değerleri ile SYBDÖ-II ve KF36 ölçeği alt boyutları karşılaştırıldığında, KF-36 alt boyutları sosyal fonksiyon $(\mathrm{r}=-0,181)$ ve ağr1 $(\mathrm{r}=-0,194)$ ile yaş arasında çok düşük düzeyde ilişki bulundu. Öğrencilerin BKİ değerleri ile SYBDÖ-II ve KF-36 ölçeği alt boyutları arasında anlamlı ilişki bulunmadı $(\mathrm{p}>0.05)$.

Tablo 3'te öğrencilerin bazı tanıtıcı özelliklerine göre ölçek toplam puan ve alt boyut puanlarının dağılımı incelendiğinde; cinsiyet ile SYBDÖ-II alt boyutu fiziksel aktivite, KF-36 alt boyutları fiziksel fonksiyon, ağrı ve genel sağlık algısı puanları arasında anlamlı bir fark bulundu. Buna göre; erkek öğrencilerin, fiziksel aktivite, fiziksel fonksiyon, ağrı ve genel sağlık algısı puanları kadınlara göre daha yüksektir $(\mathrm{p}<0.05$; $\mathrm{p}<0.01$; $\mathrm{p}<0.001)$.

Sigara kullanımı ile SYBDÖ-II alt boyutu stres yönetimi, KF-36 alt boyutları emosyonel rol kısıtlaması, vitalite ve mental sağlık puanları arasında anlamlı fark bulundu. Buna göre; sigara içmeyenlerin, stres yönetimi, emosyonel rol kısıtlaması, vitalite ve mental sağlık puanları sigara içenlere göre daha yüksektir $(\mathrm{p}<0.05)$ (Tablo 3).
Tablo 4 incelendiğinde; sınıf ile SYBDÖ-II alt boyutları sağlık sorumluluğu ve manevi gelişim ve KF- 36 alt boyutu ağrı arasında anlamlı fark bulundu $(\mathrm{p}<0.05$; $\mathrm{p}<0.01)$. Öğrencilerin yaşadığı yer ile SYBDÖ-II toplam puan, sağlık sorumluluğu, fiziksel aktivite, kişilerarası ilişki ve beslenme alt boyutları puanları arasında anlamlı fark bulundu $(\mathrm{p}<0.05 ; \mathrm{p}<0.01)$ (Tablo 4). Diğer bağımsız değişkenler ile anlamlı fark bulunmad1.

Tablo 1. Öğrencilerin Tanıtıcı Özellikleri

\begin{tabular}{|c|c|c|c|}
\hline \multicolumn{2}{|l|}{ Değişkenler } & \multicolumn{2}{|c|}{ Ortalama \pm SS } \\
\hline \multicolumn{2}{|l|}{ Yaş ortalaması } & \multicolumn{2}{|c|}{$20.5 \pm 2.04$} \\
\hline \multicolumn{2}{|c|}{ Beden kitle indeksi (BKİ) } & \multicolumn{2}{|c|}{$22.1 \pm 3.17$} \\
\hline & & Sayı (n) & $\begin{array}{c}\text { Yüzde } \\
(\%)\end{array}$ \\
\hline \multirow[t]{2}{*}{ Cinsiyet } & Kadın & 158 & 87.3 \\
\hline & Erkek & 23 & 12.7 \\
\hline \multirow[t]{4}{*}{ Sinif } & Birinci sınıf & 44 & 24.3 \\
\hline & İkinci sinıf & 55 & 30.4 \\
\hline & Üçüncü sınıf & 36 & 19.9 \\
\hline & Dördüncü sınıf & 46 & 25.4 \\
\hline \multirow[t]{3}{*}{ Aile yapıs1 } & Çekirdek aile & 164 & 90.6 \\
\hline & Geniş aile & 11 & 6.1 \\
\hline & $\begin{array}{l}\text { Parçalanmış } \\
\text { aile }\end{array}$ & 6 & 3.3 \\
\hline \multirow[t]{5}{*}{ Yaşadığı yer } & $\begin{array}{l}\text { Evde } \\
\text { ebeveynleri } \\
\text { ile }\end{array}$ & 121 & 66.9 \\
\hline & Yurtta & 32 & 17.7 \\
\hline & \begin{tabular}{|l|}
$\begin{array}{l}\text { Evde } \\
\text { arkadaşları ile }\end{array}$ \\
\end{tabular} & 17 & 9.4 \\
\hline & $\begin{array}{l}\text { Evde } \\
\text { akrabaları ile }\end{array}$ & 8 & 4.4 \\
\hline & Evde yalnız & 3 & 1.7 \\
\hline \multirow{2}{*}{$\begin{array}{|ll|}\text { Sigara } & \text { kullanma } \\
\text { durumu } & \end{array}$} & Evet & 42 & 23.2 \\
\hline & Hayır & 139 & 76.8 \\
\hline \multirow{2}{*}{$\begin{array}{ll}\text { Alkol kullanma } \\
\text { durumu }\end{array}$} & Evet & 38 & 21.0 \\
\hline & Hayır & 143 & 79.0 \\
\hline \multirow{2}{*}{$\begin{array}{|lr|}\text { Kronik hastalığa } \\
\text { sahip olma durumu }\end{array}$} & Evet & 11 & 6.1 \\
\hline & Hayır & 170 & 93.9 \\
\hline
\end{tabular}

Öğrencilerin sağlıklı yaşam biçimi davranışları ile yaşam kaliteleri arasındaki ilişki Tablo 5 'te verilmiştir. Tablo 5'e göre; öğrencilerin SYBDÖ-II toplam puanı ile ölçeğin sağlık sorumluluğu ( $\mathrm{r}=0.809)$, fiziksel aktivite $(\mathrm{r}=0.657)$, manevi gelişim $(\mathrm{r}=0.797)$, kişilerarası ilişkiler $(\mathrm{r}=0.748)$, stres yönetimi $(\mathrm{r}=0.773)$ ve beslenme $(\mathrm{r}=0.731)$ alt boyutları arasında pozitif yönde anlamlı ilişki saptand1.

SYBDÖ-II toplam puanı ile KF-36 ölçeğinin fiziksel fonksiyon $(\mathrm{r}=0.157)$ ve emosyonel rol kisitlamas1 $(\mathrm{r}=0.149)$ alt boyutları ile çok düşük, vitalite $(\mathrm{r}=0.367)$, 
mental sağlik ( $\mathrm{r}=0.323)$, sosyal fonksiyon $(\mathrm{r}=0.242)$ ve genel sağlık algısı $(r=0.261)$ ile düşük düzeyde pozitif yönde anlamlı ilişki belirlendi (Tablo 5).

Tablo 2. Öğrencilerin Sağlıklı Yaşam Biçimi Davranışları ve Yaşam Kalitesi Puan Ortalamaları

\begin{tabular}{|c|c|c|c|}
\hline $\begin{array}{|lll|}\begin{array}{l}\text { Ölçekler } \\
\text { Boyutları }\end{array} & \text { ve } & \text { Alt } \\
\end{array}$ & Ortalama \pm SS & Min. & Max. \\
\hline SYBDÖ-II & $132.52 \pm 20.05$ & 73 & 187 \\
\hline $\begin{array}{ll}\text { - } & \text { Sağlık } \\
& \text { Sorumluluğu }\end{array}$ & $21.97 \pm 4.38$ & 11 & 35 \\
\hline $\begin{array}{ll}\text { - } & \text { Fiziksel } \\
\text { Aktivite } \\
\end{array}$ & $17.89 \pm 5.21$ & 8 & 32 \\
\hline - Manevi Gelişim & $26.46 \pm 4.72$ & 12 & 36 \\
\hline $\begin{array}{ll}\text { - } & \text { Kişilerarası } \\
\text { İlişki }\end{array}$ & $26.11 \pm 4.52$ & 14 & 36 \\
\hline - $\quad$ Stres Yönetimi & $19.51 \pm 3.89$ & 11 & 31 \\
\hline - $\quad$ Beslenme & $20.5 \pm 4.00$ & 10 & 33 \\
\hline \multicolumn{4}{|l|}{ KF-36 } \\
\hline $\begin{array}{ll}- & \text { Fiziksel } \\
& \text { Fonksiyon } \\
\end{array}$ & $90.71 \pm 11.28$ & 30 & 100 \\
\hline $\begin{array}{lll}\text { - } & \text { Fiziksel Rol } \\
\text { Kisıtlaması } & \\
\end{array}$ & $86.04 \pm 28.05$ & 0 & 100 \\
\hline \begin{tabular}{ll|} 
Emosyonel Rol \\
Kisitlaması
\end{tabular} & $64.64 \pm 38.51$ & 0 & 100 \\
\hline - Vitalite & $57.34 \pm 16.10$ & 15 & 90 \\
\hline $\begin{array}{ll} & \text { Sosyal } \\
& \text { Fonksiyon } \\
\end{array}$ & $71.75 \pm 20.0$ & 25 & 100 \\
\hline - $\quad$ Ăğrı & $74.65 \pm 19.05$ & 0 & 100 \\
\hline - $\quad$ Mental Sağlık & $65.87 \pm 14.96$ & 12 & 96 \\
\hline $\begin{array}{lll} & \text { Genel } \\
\text { Algısı } & \text { Sağlık }\end{array}$ & $65.24 \pm 14.26$ & 25 & 100 \\
\hline
\end{tabular}

SYBDÖ-II ölçeğinin sağlık sorumluluğu alt boyutu ile KF-36 ölçeğinin sosyal fonksiyon $(\mathrm{r}=0.161)$ alt boyutu arasında çok düşük, vitalite $(\mathrm{r}=0.229)$ ve mental sağlık $(\mathrm{r}=0.250)$ alt boyutları arasında ise düşük düzeyde pozitif yönde anlamlı ilişki görüldü (Tablo 5).

SYBDÖ-II ölçeğinin fiziksel aktivite alt boyutu ile KF36 ölçeğinin ağrı $(\mathrm{r}=0.146)$ alt boyutu arasında çok düşük, fiziksel fonksiyon $(\mathrm{r}=0.325)$, vitalite $(\mathrm{r}=0.253)$ ve genel sağlık algısı alt boyutları $(\mathrm{r}=0.227)$ arasında ise düşük düzeyde pozitif yönde anlamlı ilişki saptandı (Tablo 5).

SYBDÖ-II ölçeğinin manevi gelişim alt boyutu ile KF36 ölçeğinin vitalite $(\mathrm{r}=0.366)$, mental sağlık $(\mathrm{r}=0.359)$, sosyal fonksiyon $(\mathrm{r}=0.294)$ ve genel sağlık algısı $(\mathrm{r}=0.277)$ alt boyutları arasında düşük düzeyde pozitif yönde anlamlı ilişki belirlendi (Tablo 5).

SYBDÖ-II ölçeğinin kişilerarası ilişki alt boyutu ile KF36 ölçeğinin sosyal fonksiyon $(\mathrm{r}=0.186)$ alt boyutu arasında çok düşük, vitalite $(\mathrm{r}=0.253)$ ve mental sağlık $(\mathrm{r}=0.339)$ alt boyutları arasında ise düşük düzeyde anlamlı ilişki görüldü (Tablo 5).
SYBDÖ-II ölçeğinin stres yönetimi alt boyutu ile KF-36 ölçeğinin emosyonel rol kısıtlaması $(\mathrm{r}=0.182)$ alt boyutu arasında çok düşük, vitalite $(\mathrm{r}=0.330)$, mental sağllk $(\mathrm{r}=0.272)$, sosyal fonksiyon $(\mathrm{r}=0.219)$ ve genel sağlık algısı ( $\mathrm{r}=0.235)$ alt boyutları arasında ise düşük düzeyde anlamlı ilişki saptandı (Tablo 5).

SYBDÖ-II ölçeğinin beslenme alt boyutu ile KF-36 ölçeğinin emosyonel rol kisıtlaması $(\mathrm{r}=0.154)$, mental sağlık (r=0.172) ve genel sağlık algısı $(\mathrm{r}=0.197)$ alt boyutları arasında çok düşük, vitalite alt boyutu $(\mathrm{r}=0.223)$ arasında ise düşük düzeyde anlamlı ilişki bulundu (Tablo 5).

\section{Tartışma}

$\mathrm{Bu}$ araştırmada; SYBDÖ-II ölçeğinin toplam puan ortalamas1 $132.52 \pm 20.05$ olarak bulundu. Şen ve arkadaşlarının (2017) sağlık hizmetleri meslek yüksekokulu öğrencileri ile yaptığı araştırmada ölçeğin toplam puan ortalaması 118.01 \pm 21.0 , Yaşar ve arkadaşlarının (2018) hemşirelik ögrencileri ile yaptığ araştırmada ölçeğin toplam puan ortalaması

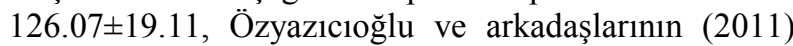
hemşirelik öğrencileri ile yaptığ 1 araştırmada ölçeğin toplam puan ortalaması $12.97 \pm 16.4$, Akgün Kostak ve arkadaşlarının (2014) hemşirelik öğrencileri ile yaptığ araştırmada ölçeğin toplam puan ortalaması $129.00 \pm 18.97$, Demir ve Baydar Artantaş'ın (2018) tıp ve hemşirelik öğrencileri ile yaptığı araştırmada ölçeğin toplam puan ortalaması $130.00 \pm 17.62$, Özveren ve Doğan Yılmaz'ın (2018) hemşirelik öğrencileri ile yaptığı araştırmada ölçeğin toplam puan ortalaması 130.69 \pm 19.2 , Tedik ve Hacialioğlu'nun (2017) hemşirelik öğrencileri ile yaptığı araştırmada ölçeğin toplam puan ortalamas1 $131.01 \pm 19.58$ ve Aksoy ve Uçar'ın (2014) hemşirelik öğrencileri ile yaptığ araştırmada ölçeğin toplam puan ortalaması $136.12 \pm 19.16$ olarak bulundu [3,13-19].

Yapılan araştırmalar incelendiğinde, bu araştırmanın bulgusunun diğer araştırmalarla benzerlik gösterdiği görüldü. SYBDÖ-II ölçeğinin puan aralığının 52-208 olduğu göz önüne alındığında, hemşirelik öğrencilerinin sağlıklı yaşam biçimi davranışlarını kendi yaşamlarına istendik düzeyde aktaramadıklarını göstermektedir.

SYBDÖ-II ölçeği alt boyutları incelendiğinde; en yüksek puan ortalamasının manevi gelişim alt boyutunda, en düşük puan ortalamasının ise fiziksel aktivite alt boyutunda olduğu ve yapılan araştırmalarla [13,14,16-19] benzerlik gösterdiği saptand1. Manevi gelişim alt boyutu puan ortalamasının yüksek olması, inançlar ve kültürün etkisi ile yorumlanabilir. Fiziksel aktivite alt boyutu puan ortalamasının düşük olması, hemşirelik öğrencilerinin fiziksel aktivitenin önemini yeterince bilmemelerinin veya bir sağlık davranışına dönüştürememelerinin sonucudur. Öte yandan, üniversite öğrencileri arasında teknoloji kullanımının giderek yaygınlaşmasının fiziksel aktivitenin azalmasına neden olduğu düşünülmektedir. 
Tablo 3: Öğrencilerin Bazı Tanıtıcı Özelliklerine Göre SYBDÖ-II, KF-36 Ölçekleri ve Alt Boyutlarının Puanlarının Dağılımı ( $\mathrm{n}=181)$

\begin{tabular}{|c|c|c|c|c|c|c|c|}
\hline Puan & Gruplar & $\mathbf{N}$ & $\begin{array}{c}\text { Sira } \\
\text { Ortalaması } \\
\end{array}$ & Sira Toplamı & $\mathbf{U}$ & $\mathbf{z}$ & $\mathbf{p}$ \\
\hline \multirow{2}{*}{ Fiziksel Aktivite } & Kadın & 158 & 85.30 & 13478.00 & \multirow{2}{*}{917.000} & \multirow{2}{*}{-3.843} & \multirow{2}{*}{$<0.001$} \\
\hline & Erkek & 23 & 130.13 & 2993.00 & & & \\
\hline \multirow{2}{*}{ Fiziksel Fonksiyon } & Kadın & 158 & 87.41 & 13810.50 & \multirow{2}{*}{1249.500} & \multirow{2}{*}{-2.498} & \multirow{2}{*}{$0.013 *$} \\
\hline & Erkek & 23 & 115.67 & 2660.50 & & & \\
\hline \multirow{2}{*}{ Ağrı } & Kadın & 158 & 87.06 & 13756.00 & \multirow{2}{*}{1195.000} & \multirow{2}{*}{-2.676} & \multirow{2}{*}{$0.007 * *$} \\
\hline & Erkek & 23 & 118.04 & 2715.00 & & & \\
\hline \multirow{2}{*}{$\begin{array}{l}\text { Genel Sağlık } \\
\text { Algısı }\end{array}$} & Kadın & 158 & 86.91 & 13732.00 & \multirow{2}{*}{1171.000} & \multirow{2}{*}{-2.771} & \multirow{2}{*}{$0.006 * *$} \\
\hline & Erkek & 23 & 119.09 & 2739.00 & & & \\
\hline \multirow{2}{*}{$\begin{array}{l}\text { Stres } \\
\text { Yönetimi }\end{array}$} & Sigara içmeyenler & 139 & 96.47 & 13409.00 & \multirow{2}{*}{2159.000} & \multirow{2}{*}{-2.563} & \multirow{2}{*}{$0.010 *$} \\
\hline & Sigara içenler & 42 & 72.90 & 3062.00 & & & \\
\hline \multirow{2}{*}{$\begin{array}{l}\text { Emosyonel Rol } \\
\text { Kisıtlaması } \\
\end{array}$} & Sigara içmeyenler & 139 & 95.27 & 13243.00 & \multirow{2}{*}{2325.000} & \multirow{2}{*}{-2.124} & \multirow{2}{*}{$0.034 *$} \\
\hline & Sigara içenler & 42 & 76.86 & 3228.00 & & & \\
\hline \multirow{2}{*}{ Vitalite } & Sigara içmeyenler & 139 & 95.96 & 13338.00 & \multirow{2}{*}{2230.000} & \multirow{2}{*}{-2.327} & \multirow{2}{*}{$0.020 *$} \\
\hline & Sigara içenler & 42 & 74.60 & 3133.00 & & & \\
\hline \multirow{2}{*}{$\begin{array}{l}\text { Mental } \\
\text { Sağlık }\end{array}$} & Sigara içmeyenler & 139 & 95.59 & 13287.00 & \multirow{2}{*}{2281.000} & \multirow{2}{*}{-2.154} & \multirow{2}{*}{$0.031 *$} \\
\hline & Sigara içenler & 42 & 75.81 & 3184.00 & & & \\
\hline
\end{tabular}

Mann-Whitney U testi *p<0.05**p<0.01

Tablo 4: Öğrencilerin Bazı Tanıtıcı Özelliklerine Göre SYBDÖ-II, KF-36 Ölçekleri ve Alt Boyutlarının Puanlarının Dağılımı (n=181)

\begin{tabular}{|c|c|c|c|c|c|c|}
\hline Puan & Gruplar & $\mathbf{N}$ & $\begin{array}{l}\text { Sira } \\
\text { Ortalaması }\end{array}$ & $\mathbf{X}^{2}$ & sd & $\mathbf{p}$ \\
\hline \multirow{4}{*}{$\begin{array}{l}\text { Sağlık } \\
\text { Sorumluluğu }\end{array}$} & Birinci Sınıf & 44 & 75.14 & \multirow{4}{*}{8.220} & \multirow{4}{*}{3} & \multirow{4}{*}{$0.042 *$} \\
\hline & İkinci Sınıf & 55 & 98.68 & & & \\
\hline & Üçüncü Sınıf & 36 & 83.78 & & & \\
\hline & Dördüncü Sınıf & 46 & 102.64 & & & \\
\hline \multirow{4}{*}{$\begin{array}{l}\text { Manevi } \\
\text { Gelişim }\end{array}$} & Birinci Sinıf & 44 & 93.17 & \multirow{4}{*}{8.142} & \multirow{4}{*}{3} & \multirow{4}{*}{$0.043 *$} \\
\hline & İkinci Sınıf & 55 & 97.54 & & & \\
\hline & Üçüncü Sınıf & 36 & 69.10 & & & \\
\hline & Dördüncü Sınıf & 46 & 98.25 & & & \\
\hline \multirow{4}{*}{ A ğgrı } & Birinci Sinıf & 44 & 104.06 & \multirow{4}{*}{12.807} & \multirow{4}{*}{3} & \multirow{4}{*}{$0.005 * *$} \\
\hline & İkinci Sınıf & 55 & 101.38 & & & \\
\hline & Üçüncü Sınıf & 36 & 85.89 & & & \\
\hline & Dördüncü Sınıf & 46 & 70.10 & & & \\
\hline \multirow{5}{*}{ SYBDÖ - II Toplam Puan } & Evde ebeveynleri ile & 121 & 99.91 & \multirow{5}{*}{17.121} & \multirow{5}{*}{4} & \multirow{5}{*}{$0.002 * *$} \\
\hline & Yurtta & 32 & 75.72 & & & \\
\hline & Evde arkadaşları ile & 17 & 50.62 & & & \\
\hline & Evde akrabaları ile & 8 & 93.13 & & & \\
\hline & Evde yalnız & 3 & 117.67 & & & \\
\hline \multirow{5}{*}{ Sağlık Sorumluluğu } & Evde ebeveynleri ile & 121 & 96.80 & \multirow{5}{*}{10.788} & \multirow{5}{*}{4} & \multirow{5}{*}{$0.029 *$} \\
\hline & Yurtta & 32 & 83.03 & & & \\
\hline & Evde arkadaşları ile & 17 & 62.97 & & & \\
\hline & Evde akrabaları ile & 8 & 75.31 & & & \\
\hline & Evde yaln1z & 3 & 142.67 & & & \\
\hline \multirow{5}{*}{ Fiziksel Aktivite } & Evde ebeveynleri ile & 121 & 99.26 & \multirow{5}{*}{12.976} & \multirow{5}{*}{4} & \multirow{5}{*}{ 0.011* } \\
\hline & Yurtta & 32 & 75.88 & & & \\
\hline & Evde arkadaşları ile & 17 & 57.24 & & & \\
\hline & Evde akrabaları ile & 8 & 93.88 & & & \\
\hline & Evde yalnız & 3 & 103.00 & & & \\
\hline \multirow{5}{*}{ Kişilerarası İlişski } & Evde ebeveynleri ile & 121 & 98.59 & \multirow{5}{*}{11.305} & \multirow{5}{*}{4} & \\
\hline & Yurtta & 32 & 81.23 & & & \\
\hline & Evde arkadaşları ile & 17 & 56.82 & & & $0.024 *$ \\
\hline & Evde akrabaları ile & 8 & 94.44 & & & \\
\hline & Evde yalnız & 3 & 73.50 & & & \\
\hline & Evde ebeveynleri ile & 121 & 96.76 & & & \\
\hline & Yurtta & 32 & 76.28 & & & \\
\hline Beslenme & Evde arkadaşları ile & 17 & 64.21 & 11.048 & 4 & $0.026 *$ \\
\hline & Evde akrabaları ile & 8 & 103.13 & & & \\
\hline & Evde yalnız & 3 & 135.00 & & & \\
\hline
\end{tabular}

Kruskal-Wallis H testi $* \mathrm{p}<0.05 * * \mathrm{p}<0.01$

Obezite açısından risk altında olan bu yaş grubunun düzenli egzersiz uygulamaları için öncelikle ailesi ve öğretim elemanları tarafından desteklenmesi gerekmektedir. $\mathrm{Bu}$ araştırmada fiziksel aktivite ile fiziksel fonksiyon arasında pozitif yönde anlamlı ilişki bulundu. Dolayısıyla, fiziksel aktivitenin artması öğrencilerin fiziksel fonksiyonlarının gelişmesine de katkı sağlayacaktır.

KF-36 ölçeğinin alt boyutları incelendiğinde ise; en yüksek puan ortalamasının fiziksel fonksiyon alt boyutunda, en düşük puan ortalamasının ise vitalite alt 
Tablo 5. Öğrencilerin Sağıııı Yaşam Biçimi Davranışları İle Yaşam Kaliteleri Arasındaki İlişki (n=181)

\begin{tabular}{|c|c|c|c|c|c|c|c|c|c|}
\hline Değişkenler & $\begin{array}{l}\text { SYBDÖ-II } \\
\text { Toplam }\end{array}$ & \begin{tabular}{|l|} 
Fiziksel \\
Fonksiyon
\end{tabular} & $\begin{array}{l}\text { Fiziksel Ro } \\
\text { nisitlaması }\end{array}$ & $\begin{array}{l}\text { Emosyonel } \\
\text { Rol } \\
\text { Kisitlamas1 }\end{array}$ & Vitalite & $\begin{array}{l}\text { Mental } \\
\text { Sağlık }\end{array}$ & \begin{tabular}{|l} 
Sosyal \\
Fonksiyon
\end{tabular} & Ăgrn & \begin{tabular}{|l} 
Genel \\
Sağlık \\
Algıs1
\end{tabular} \\
\hline $\begin{array}{l}\text { SYBDÖ-II } \\
\text { Toplam }\end{array}$ & 1 & $.157 *$ & 119 & $.149 *$ & $.367 * * *$ & $.323^{* * * *}$ & $.242 * *$ & .089 & $.261 * * *$ \\
\hline \begin{tabular}{|l|} 
Fiziksel \\
Fonksiyon \\
\end{tabular} & $.157 *$ & 1 & $.297 * * *$ & $.221 * *$ & $.195 * *$ & .072 & $.155^{*}$ & $.234 * *$ & $.289 * * *$ \\
\hline 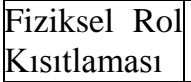 & .119 & $.297 * * *$ & 1 & $.261 * * *$ & $.207 * *$ & $.178 * *$ & $.262 * * *$ & $.201 * *$ & $.285 * * *$ \\
\hline $\begin{array}{l}\text { Emosyonel } \\
\text { Rol } \\
\text { Kisitlamas } 1 \\
\end{array}$ & $.149 *$ & $.221 * *$ & $.261 * * *$ & 1 & $.391 * * * *$ & $.365^{* * * *}$ & $.304 * * *$ & $.191 *$ & $.254 * *$ \\
\hline Vitalite & $.367 * * *$ & $.195 * *$ & $.207 * *$ & $.391 * * *$ & 1 & $.637 * * *$ & $.414 * * *$ & $.256 * *$ & $.397 * * *$ \\
\hline $\begin{array}{l}\text { Mental } \\
\text { Sağllk }\end{array}$ & $.323 * * *$ & .072 & $.178 * *$ & $.365 * * *$ & $.637 * * * *$ & 1 & $.382 * * *$ & .086 & $.306 * * *$ \\
\hline \begin{tabular}{|l|} 
Sosyal \\
Fonksiyon
\end{tabular} & $.242 * *$ & $.155^{*}$ & $.262^{* * * *}$ & $.304 * * *$ & $.414 * * *$ & $.382^{* * * *}$ & 1 & $.414 * * * *$ & $.428 * * *$ \\
\hline Ağrn & .089 & $.234 * *$ & $.201 * *$ & $.191 *$ & $.256 * *$ & .086 & $.414 * * *$ & 1 & $.327 * * *$ \\
\hline $\begin{array}{l}\text { Genel } \\
\text { Sağllk } \\
\text { Algis1 }\end{array}$ & $.261 * * *$ & $.289 * * *$ & $.285 * * *$ & $.254 * *$ & $.397 * * *$ & $.306 * * *$ & $.428 * * *$ & $.327 * * *$ & 1 \\
\hline
\end{tabular}

boyutunda olduğu saptandı. Aynı zamanda vitalite alt boyutu ile SYBDÖ-II ölçeği toplam puanı ve alt boyutları arasında pozitif yönde anlamlı ilişki bulundu. $\mathrm{Bu}$ durum, öğrencilerin yaşam kalitelerini orta düzeyin üstünde değerlendirmelerine karşın enerjilerinin istendik düzeyde olmadığını göstermektedir. Öğrencilerin, müfredat programının yoğunluğunun ve uzun süreli teknoloji kullanımlarının yetersiz uyku süresi ve dengesiz beslenmeye neden olarak enerji düşüklüğüne yol açabileceği düşünülmektedir.

KF-36 ölçeğinin mental sağlık alt boyutu ile SYBDÖ-II ölçeği toplam puanı, sağlık sorumluluğu, manevi gelişim, kişilerarası ilişkiler, stres yönetimi ve beslenme alt boyutları arasında pozitif yönde anlamlı ilişki belirlendi. Öğrencilerin ruhsal açıdan sağlıklı olmaları, sağlıklı yaşam biçimi davranışlarını uygulamalarında önemli etkenlerden biridir. Ruhsal açıdan sağlıklı olan birey; fiziksel ve ruhsal iyilik halini değerlendirebilir, ailesi ve çevresindeki bireyler ile etkili iletişim kurabilir ve stres ve zorluklar ile sahip olduğu öz yeterlik, iyimserlik, umut gibi koruyucu özellikler sayesinde baş edebilir.

KF-36 ölçeğinin sosyal fonksiyon alt boyutu ile SYBDÖ-II ölçeği toplam puanı, sağlık sorumluluğu, manevi gelişim, kişilerarası ilişkiler ve stres yönetimi alt boyutları arasında pozitif yönde anlamlı ilişki görüldü.

Öğrencilerin sosyal fonksiyonlarını sürdürebilmeleri, birey olarak kendi sağlığını değerlendirebilmelerini, akademik başarısını arttırmasını, etkili kişilerarası ilişkiler kurmasını ve yönetmesini sağlayabilir.

KF-36 ölçeğinin genel sağlık algısı alt boyutu ile SYBDÖ-II ölçeği toplam puanı, fiziksel aktivite, manevi gelişim, stres yönetimi ve beslenme alt boyutları arasında pozitif yönde anlamlı ilişki saptandı. Mak ve arkadaşları tarafindan (2018) 538 hemşirelik öğrencisi ile sağlığı geliştirici yaşam tarzı ile yaşam kalitesi arasındaki ilişkiyi belirlemek amacıyla yapılan araştırmada da yaşam kalitesi ile sağlık sorumluluğu, fiziksel aktivite, manevi gelişim ve stres yönetimi arasında pozitif yönde anlamlı ilişki bulunmuştur [20]. Öğrencilerin yeterli ve dengeli beslenmeleri, düzenli egzersiz uygulamaları ve günlük yaşam stresi ile etkili baş edebilmeleri genel sağlık algılarını arttırabilir. $\mathrm{Bu}$ durum öğrencilerin akademik başarılarını da olumlu yönde etkileyebilir.

Sigara kullanımı, zayıf diyet, sedanter yaşam ve aşırı alkol tüketimi gibi sağlıksız yaşam biçimleri morbidite ve mortaliteye yol açmaktadır [21] ve bu durum bireyin yaşamını altı y1l kısaltabilir [22]. Geç adölesanlık sırasında hemşirelik öğrencilerinin sağlıksız yaşam tarzı, yetişkinlikte uzun dönemli yan etkilere neden olabilir. Bu nedenle, erken dönemde sağlıklı yaşam biçimi davranışlarında yapılacak değişiklikler daha olumlu sağlık çıktıları ile sonuçlanabilir.

$\mathrm{Bu}$ araştırma; araştırmada kullanılan veri toplama araçlarının kapsadığı boyutlarla, araştırmaya katılan öğrencilerin görüşleriyle ve araştırmanın bir vakıf üniversitesinin Hemşirelik bölümü öğrencileriyle yürütülmesinden dolayı genellenememesiyle sınırlıdır.

\section{Sonuç}

$\mathrm{Bu}$ araştırmanın sonucunda hemşirelik öğrencilerinin sağlıklı yaşam biçimi davranışları ile yaşam kaliteleri arasında istatistiksel açıdan anlamlı ilişkinin olduğu belirlendi. Bu sonuçlar doğrultusunda;

- Öğrencilerin sağlıklı yaşam biçimi davranışlarını ve yaşam kalitelerini geliştirmek 
için kampüs içerisinde sağlı̆̆ı geliştirme programlarının planlanması ve uygulanması,

- Öğrencilerin öğrenim hayatları boyunca kültürel, sportif ve sosyal etkinliklere katılımları konusunda desteklenmesi,

- Eğitim müfredatına beslenme, fiziksel aktivite, stres yönetimi ve kendini tanıma konularına yönelik seçmeli derslerin eklenmesi,

- Öğrencilerin biyopsikososyal yaklaşım ile değerlendirilerek, öğrencilere danışmanlık hizmetinin verilmesi ve düzenli aralıklarla izlemlerinin yapılması,

- Öğrencilerde sağlığ́ geliştirme programlarının etkinliğini değerlendirmeye yönelik deneysel çalışmaların yapılması önerilmektedir.

\section{Kaynaklar}

1. Cihangiroğlu Z, Deveci SE. Healthy life style behaviours and related influencing factors of the students of Elazig high school of Health Sciences of Firat University. Frrat Medical of Journal. 2011;16(2):78-83.

2. İlhan N, Batmaz M, Akhan LU. Üniversite öğrencilerinin sağlıklı yaşam biçimi davranışları. Maltepe Üniversites Hemșirelik Bilim ve Sanatı Dergisi. 2010;3(3):34-44.

3. Özyazıcıŏ̆lu N, Kılıç M, Erdem N, Yavuz C, Afacan S. Hemşirelik öğrencilerinin sağlıklı yaşam biçimi davranışlarının belirlenmesi. Uluslararası İnsan Bilimleri Dergisi. 2011; 8(2):277-332.

4. Zaybak A, Fadıloğlu Ç. Üniversite öğrencilerinin sağlığ geliştirme davranışı ve bu davranışı etkileyen etmenlerin belirlenmesi. Ege Üniversitesi Hemşirelik Yüksek Okulu Dergisi. 2004;20(1):77-95

5. Açıksöz S, Uzun Ş, Arslan F. Hemşirelik öğrencilerinin sağlık algısı ile sağlığı geliștirme davranıșları arasındaki ilişkinin incelenmesi. Gülhane Tıp Dergisi. 2013; 55(3):e181

6. Ayaz S, Tezcan S, Akıncı F. Hemşsirelik yüksekokulu öğrencilerinin sağlığı geliştirme davranışları. Cumhuriyet Üniversitesi Hemsirelik Yüksekokulu Dergisi. 2005;9(2):2634.

7. Haddad L, Kane D, Rajacich D, Cameron S, Al-Ma'aitah, R. (2004). A comparison of health practices of Canadian and Jordanian nursing students. Public Health Nursing. 2004;21(1):85-90.

8. Hui WH. The health-promoting lifestyles of undergraduate nurses in Hong Kong. Journal on Professional Nursing. 2002; 18(2):101-11

9. Ünalan D, Şenol V, Öztürk A, Erkorkmaz Ü. Meslek yüksekokullarının sağlık ve sosyal programlarında öğrenim gören öğrencilerin sağlıklı yaşam biçimi davranışları ve özbakım gücü düzeyleri arasındaki ilișkinin incelenmesi. Turgut Özal Tıp Merkezi Dergisi. 2007;14(2):101-9

10. Özbaşaran F, Çetinkaya AÇ, Güngör N. Celal Bayar Üniversitesi sağlık yüksekokulu öğrencilerinin sağlık davranışları. Atatürk Üniversitesi Hemşirelik Yüksekokulu Dergisi. 2004:7(3):43-55.

11. Bahar Z, Beşer A, Gördes N, Ersin F, Kıssal A. Sağlıklı yaşam biçimi davranışları ölçeği II'nin geçerlik ve güvenirlik çalışması. Cumhuriyet Üniversitesi Hemşirelik Yüksekokulu Dergisi. 2008;12(1):1-13.

12. Koçyiğit H, Aydemir O, Fișek G, Ölmez N, Memis A. Short Form-36's Reliability and validity of the Turkish version. İlaç ve Tedavi Dergisi. 1999;12:102-6.

13. Sen MA, Ceylan A, Kurt ME, Palancı Y, Adın C. Sağlık hizmetleri meslek yüksekokulu öğrencilerinin sağlıklı yaşam biçimi davranıșları ve etkileyen faktörler. Dicle Tıp Dergisi. 2017;44(1):1-11

14. Yaşar Ö, Karadağ N, Özsever Kaymak G. Hemşirelik bölümü öğrencilerinin sağlıklı yaşam biçimi davranışlarının incelenmesi. Balıkesir Sağlık Bilimleri Dergisi. 2018;7(3):81-6.
15. Kostak MA, Kurt S, Süt N, Akarsu Ö, Ergül GD. Hemșirelik ve sınıf öğretmenliği öğrencilerinin sağlıklı yaşam biçimi davranışları. TAF Prev Med Bull. 2014;13(3):189-196.

16. Demir E, Baydar Artantaș A. Tıp ve hemşirelik öğrencilerinde sağlıklı yaşam biçimi davranışlarının değerlendirilmesi: kesitsel bir çalışma. Ankara Med J. 2018;(2):186-197.

17. Özveren H, Doğan Yılmaz E. Hemşirelik öğrencilerinin sağlıklı yaşam biçimi davranışları ile egzersiz davranışlarının incelenmesi. Journal of Human Sciences. 2018;15(3):150518.

18. Tedik SE, Hacialioğlu N. Hemşirelik öğrencilerinde fazla kilo durumu ve sağlıklı yașam biçimi davranıșları arasındaki ilişkinin incelenmesi. Uluslararası Hakemli Hemşirelik Araştırmaları Dergisi. 2017;10:59-82

19. Aksoy T, Uçar H. Hemsirelik öğrencilerinin sağlıklı yaşam biçimi davranışları. Hacettepe Üniversitesi Hemşirelik Fakültesi Dergisi. 2014;1(2):53-67.

20. Mak YW, Kao AH, Tam LW, Virginia WC, Don TH, Leung DY. Health-promoting lifestyle and quality of life among Chinese nursing students. Primary Health Care Research \& Development. 2018;19(6):629-36

21. Türkiye İstatistik Kurumu. Ölüm Nedeni İstatistikleri 2017 (Erişim tarihi: 27.11.2018). Erişim adresi: http://www.tuik.gov.tr/HbPrint.do?id=24572

22. Manuel DG, Perez R, Sanmartin C, Taljaard M, Hennessy D, Wilson K, Tanuseputro P, Manson H, Bennett C, Tuna M, Fisher S, Rosella LC. Measuring burden of unhealthy behaviours using a multivariable predictive approach: life expectancy lost in Canada attributable to smoking, alcohol, physical inactivity, and diet. PLoS Med 2016;13(8):e1002082.

http://edergi.cbu.edu.tr/ojs/index.php/cbusbed isimli yazarın CBU-SBED başlıklı eseri bu Creative Commons Alınt1-Gayriticari4.0 Uluslararası Lisansı ile lisanslanmıştır. 